\title{
Spectroscopic Methods in the Evaluation of Modified Vegetable Base Oils from Crambe abyssinica
}

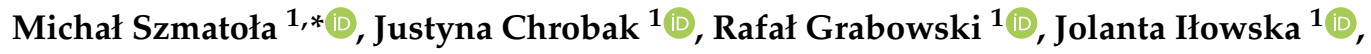 \\ Julia Woch ${ }^{1}{ }^{\circledR}$, Iwona Szwach ${ }^{1}$, Izabela Semeniuk ${ }^{1}$, Jolanta Drabik ${ }^{2}{ }^{\oplus}$, Małgorzata Wrona ${ }^{2}$, \\ Rafał Kozdrach ${ }^{2}$, Beata Orlińska ${ }^{3}$ (D) and Mirosława Grymel ${ }^{4,5}$ (D) \\ 1 Institute of Heavy Organic Synthesis "Blachownia”, Energetykow 9, 47-225 Kedzierzyn-Kozle, Poland; \\ chrobak.j@icso.com.pl (J.C.); grabowski.r@icso.com.pl (R.G.); ilowska.j@icso.com.pl (J.I.); \\ woch.j@icso.com.pl (J.W.); szwach.i@icso.com.pl (I.S.); semeniuk.i@icso.com.pl (I.S.) \\ 2 The Institute for Sustainable Technologies-National Research Institute, Kazimierza Pulaskiego 6/10, \\ 26-600 Radom, Poland; jolanta.drabik@itee.radom.pl (J.D.); malgorzata.wrona@itee.radom.pl (M.W.); \\ rafal.kozdrach@itee.radom.pl (R.K.) \\ 3 Department of Organic Chemical Technology and Petrochemistry, Silesian University of Technology, B. \\ Krzywoustego 4, 44-100 Gliwice, Poland; beata.orlinska@polsl.pl \\ 4 Department of Organic Chemistry, Bioorganic Chemistry and Biotechnology, Silesian University of \\ Technology, B. Krzywoustego 4, 44-100 Gliwice, Poland; miroslawa.grymel@polsl.pl \\ 5 Biotechnology Center of Silesian University of Technology, B. Krzywoustego 8, 44-100 Gliwice, Poland \\ * Correspondence: szmatola.m@icso.com.pl; Tel.: +48-77-487-3297
}

Received: 22 November 2018; Accepted: 5 December 2018; Published: 7 December 2018

check for updates

\begin{abstract}
Raw vegetable oil from Crambe abyssinica was subjected to oxidative treatment to enhance its viscosity. The oxidation processes were carried out in the presence of $N$-hydroxyphthalimide with or without supercritical $\mathrm{CO}_{2}$ as a solvent. Four spectroscopic techniques (Raman, UV-VIS, FT-IR, NMR) were applied to assess the chemical changes taking place during the oxidation. Raman and NMR spectroscopy proved best in the assessment of the chemical transformations leading to increased viscosity of the modified vegetable oil.
\end{abstract}

Keywords: vegetable oil; Crambe abyssinica oil; chemical modification; oxidation; $N$-hydroxyphthalimide; Raman spectroscopy

\section{Introduction}

Oils are a group of products which are characterized by a high variability of their chemical and physical properties. The chemical analysis of vegetable oils is arduous because they consist of complex mixtures of chemical compounds and the evaluation of the results can also be disturbed by a matrix effect [1]. However, characterization of these oils can be performed using a great variety of analytical methods and chemometric methodologies. Different techniques for fats and oils analysis have been developed so far and a large part of them is based on liquid or gas chromatography [2,3].

There has been a growing demand to replace traditional analytical methods with instrumental methods. The superiority of the latter is due to their high sensitivity, low limits of detection, speed of analysis and automated operation. Modern instrumental techniques include spectroscopic methods that are successfully used in qualitative and quantitative analysis in various industries, including the chemical and food industries, electronics or metallurgy. Furthermore, spectroscopic methods can be used in conjunction with advanced separation methods, which apart from comprehensive qualitative and quantitative analysis of isolated intermediates, enable the direct analysis of final products. Numerous scientific publications prove the usefulness of spectroscopic methods in the study of the properties of vegetable oils and, above all, the assessment of 
the quality of edible oils $[4,5]$. The analysis of vegetable oils can be carried out with the use of absorption spectroscopy in the area of the ultraviolet-visible spectral region (UV-Vis) [6-8], infrared spectroscopy (IR) [9-14], nuclear magnetic resonance spectroscopy (NMR) [15-17] and Raman spectroscopy [18-21].

The performance of base oils mostly depends on their physiochemical properties. The characteristics of base oils play a key role in the ultimate formulation of high-quality lubricants. Several publications concern the use of instrumental methods to determine the properties of various base oils [22-26] and lubricants [27-32]. However, these articles relate mainly to the analysis of mineral or synthetic base oils. Lubricants based on vegetable oils seem to be an attractive alternative to conventional lubricants. Structurally, vegetable oils are mixtures of natural fatty acid esters and are an alternative to replace the commonly used mineral oils due to their natural occurrence and their fast biodegradation rates which could reduce environmental risks.

The base oils obtained in the innovative process of vegetable oils modification, presented in our previous article [33], were subjected to various tests to determine the changes that have occurred in the chemical composition. The aim of this paper is to demonstrate the applicability of spectroscopic techniques, including UV-VIS spectroscopy, NMR, infrared and Raman spectroscopy, as the methods of analysis to evaluate the result of the modification reactions and determine their effect on the structural changes between unmodified vegetable oils and oil bases obtained as a result of oxidation reactions.

\section{Results and Discussion}

\subsection{Oxidative Modification of Raw Crambe Oil}

The raw vegetable oil from Crambe abyssinica (A) is characterized by a high content of both unsaturated erucic acid and natural antioxidants. Crambe abyssinica belongs to the cabbage family (Brassicaceae). It is an oilseed crop which originated from the Mediterranean region. It has also been grown in other regions e.g., tropical and subtropical parts of Africa, Central and West Asia, Europe, North and South America [34]. The oil is used as a lubricant, corrosion inhibitor and in the production of synthetic rubbers, nylons or plastic films [35]. The raw oil was modified to obtain higher viscosity class (VG 150) oils via an oxidative treatment. The oil, catalyst, radical initiator and solvent were vigorously stirred at elevated temperature and pressure under an oxygen atmosphere. The process was stopped after a specified amount of oxygen had been absorbed. N-Hydroxyphthtalimide (NHPI) was used as a catalyst, azobisisobutyronitrile (AIBN) as a radical initiator and supercritical carbon dioxide $\left(\mathrm{scCO}_{2}\right)$ as a solvent. Reactions without $\mathrm{scCO}_{2}$ were performed for comparison. The modified oils were marked as $\mathrm{A} \_\mathrm{CO}_{2}$ and $\mathrm{A} \_\mathrm{O}_{2}$ accordingly. After the experiments all modified oils were tested to determine their kinematic viscosity, peroxide number (LN), iodine number (LJ), saponification number (LZ) and acid number (LK). The results are summarized in Table 1 . In this Table, mean values of the measurements (three repetitions) and the values of standard deviations are presented.

Table 1. Analytical figures for the starting material (raw Abyssinian oil (A)) and the oil modified in the presence of the solvent $\left(\mathrm{A} \_\mathrm{CO}_{2}\right)$ and in oxygen atmosphere, without solvent $\left(\mathrm{A} \_\mathrm{O}_{2}\right)$.

\begin{tabular}{|c|c|c|c|c|c|c|}
\hline \multirow[b]{2}{*}{ Oil } & \multicolumn{2}{|c|}{ A } & \multicolumn{2}{|c|}{ A_CO $\mathrm{CO}_{2}$} & \multicolumn{2}{|c|}{ A_O ${ }_{2}$} \\
\hline & Mean Value & $\begin{array}{l}\text { Standard } \\
\text { Deviation }\end{array}$ & Mean Value & $\begin{array}{l}\text { Standard } \\
\text { Deviation }\end{array}$ & Mean Value & $\begin{array}{l}\text { Standard } \\
\text { Deviation }\end{array}$ \\
\hline Kinematic viscosity at $40^{\circ} \mathrm{C}, \mathrm{mm}^{2} / \mathrm{s}$ & 48.20 & \pm 0.35 & 143.40 & \pm 0.54 & 156.90 & \pm 0.26 \\
\hline Kinematic viscosity at $100^{\circ} \mathrm{C}, \mathrm{mm}^{2} / \mathrm{s}$ & 10.10 & \pm 0.05 & 16.10 & \pm 0.07 & 17.20 & \pm 0.08 \\
\hline $\mathrm{LN}$, meq $\mathrm{O}_{2} / \mathrm{kg}$ & 2.80 & \pm 0.09 & 13.10 & \pm 0.31 & 15.16 & \pm 0.54 \\
\hline $\mathrm{LJ}, \mathrm{g} \mathrm{I}_{2} / 100 \mathrm{~g}$ & 83.48 & \pm 0.65 & 63.70 & \pm 0.57 & 54.10 & \pm 0.48 \\
\hline $\mathrm{LZ}, \mathrm{mg} \mathrm{KOH} / \mathrm{g}$ & 170.50 & \pm 0.76 & 248.70 & \pm 0.91 & 214.23 & \pm 0.67 \\
\hline $\mathrm{LK}, \mathrm{mg} \mathrm{KOH} / \mathrm{g}$ & 0.34 & \pm 0.04 & 28.05 & \pm 0.04 & 25.70 & \pm 0.02 \\
\hline
\end{tabular}

Conditions: reaction time $5 \mathrm{~h}$; temperature $120{ }^{\circ} \mathrm{C}$; NHPI $0.05 \%(w / w)$; $\mathrm{AIBN} 0.05 \%(w / w)$; stirring at $1000 \mathrm{rpm}$, oxygen pressure $2.5 \mathrm{MPa}$, total pressure $10 \mathrm{MPa}\left(\mathrm{A}_{-} \mathrm{CO}_{2}\right)$; oxygen pressure maintained at constant $0.4 \mathrm{MPa}\left(\mathrm{A}, \mathrm{A} \_\mathrm{O}_{2}\right)$. 


\subsection{Oxidative Stability Tests of the Modified Oils}

The raw vegetable oil (A) with VG 46 viscosity class and VG $150\left(\mathrm{~A}_{-} \mathrm{CO}_{2}\right.$ and $\left.\mathrm{A} \_\mathrm{O}_{2}\right)$ oils obtained through modification were subjected to Rapid Small Scale Oxidation Test (RSSOT, PetroOxy) to evaluate their oxidation stability. This method consists in the acceleration of the oxidation process for a chosen sample at an elevated temperature and exposure to the excess of oxygen. The sample is placed in a small chamber and is exposed to the oxygen under pressure at a certain temperature. The temperature is kept constant and the pressure is constantly measured until a specified pressure drop is detected. During our research tests were performed in isothermal conditions, at $80^{\circ} \mathrm{C}$ and $120^{\circ} \mathrm{C}$. Measurements were taken until pressure dropped by $10 \%$. The time of oxidation induction was determined on that basis (Table 2). In this Table, mean values of the measurements (three repetitions) and the values of standard deviations are presented.

Table 2. Properties of the starting materials and results of the PetroOxy tests.

\begin{tabular}{|c|c|c|c|c|c|c|}
\hline \multirow[b]{2}{*}{ Oil } & \multicolumn{2}{|c|}{ A } & \multicolumn{2}{|c|}{ A_CO $\mathrm{CO}_{2}$} & \multicolumn{2}{|c|}{ A_O $\mathrm{O}_{2}$} \\
\hline & Mean Value & $\begin{array}{c}\text { Standard } \\
\text { Deviation }\end{array}$ & Mean Value & $\begin{array}{c}\text { Standard } \\
\text { Deviation }\end{array}$ & Mean Value & $\begin{array}{c}\text { Standard } \\
\text { Deviation }\end{array}$ \\
\hline VG viscosity class, ISO 3448 & 46 & - & 150 & - & 150 & - \\
\hline LJ, g I2/100 g & 83.48 & \pm 0.65 & 63.70 & \pm 0.57 & 54.10 & \pm 0.48 \\
\hline Oxidation induction time at $80^{\circ} \mathrm{C}, \mathrm{h}$ & 32.80 & \pm 2.62 & 2.71 & \pm 0.22 & 2.38 & \pm 0.19 \\
\hline Oxidation induction time at $120^{\circ} \mathrm{C}, \mathrm{h}$ & 2.55 & \pm 0.20 & 0.66 & \pm 0.05 & 0.67 & \pm 0.05 \\
\hline
\end{tabular}

\subsection{Spectroscopic Methods}

The obtained oils were analyzed using spectroscopic techniques. For the following materials, Raman, UV-VIS, IR and NMR spectra were recorded: raw vegetable oil (A) with VG 46 viscosity class before and after the PetroOxy test (A_80, A_120 for samples tested at $80^{\circ} \mathrm{C}$ and $120^{\circ} \mathrm{C}$ respectively); modified oils $\left(\right.$ A_O ${ }_{2}$ and $\left.A \_\mathrm{CO}_{2}\right)$ with VG 150 viscosity class before and after the PetroOxy test $\left(\mathrm{A}_{-} \mathrm{O}_{2}{ }_{8} 80\right.$ and A_O $2 \_120$; A_CO 2 _80 and A_CO ${ }_{2}$ 120, for samples tested at $80^{\circ} \mathrm{C}$ and $120^{\circ} \mathrm{C}$ respectively).

\subsubsection{Raman Spectroscopy}

The raw vegetable oil from Crambe abyssinica (A) is composed mainly of unsaturated fatty acids with the following molecular structure: erucic acid (C22:1, 63.77\%), oleic acid (C18:1, 15.07\%), linoleic acid $(\mathrm{C} 18: 2,13.16 \%)$ and linolenic acid (C18:3) $[36,37]$. Unsaturation is the main cause of the reactivity of the oil towards oxygen.

Figure 1 shows the Raman spectra of oils obtained in the modification process $\left(\mathrm{A}_{-} \mathrm{CO}_{2}\right.$ and $\left.\mathrm{A} \_\mathrm{O}_{2}\right)$ in comparison with the raw oil (A). The use of Raman spectroscopy allowed us to evaluate the influence of the modification process and thermal activation on changes in structure of the researched oils. The band assignments of the Raman spectra of initial A oil and modified $\mathrm{A}_{-} \mathrm{CO}_{2}$ and $\mathrm{A} \_\mathrm{O}_{2}$ oils are reported in Table 3 [38-43]. 


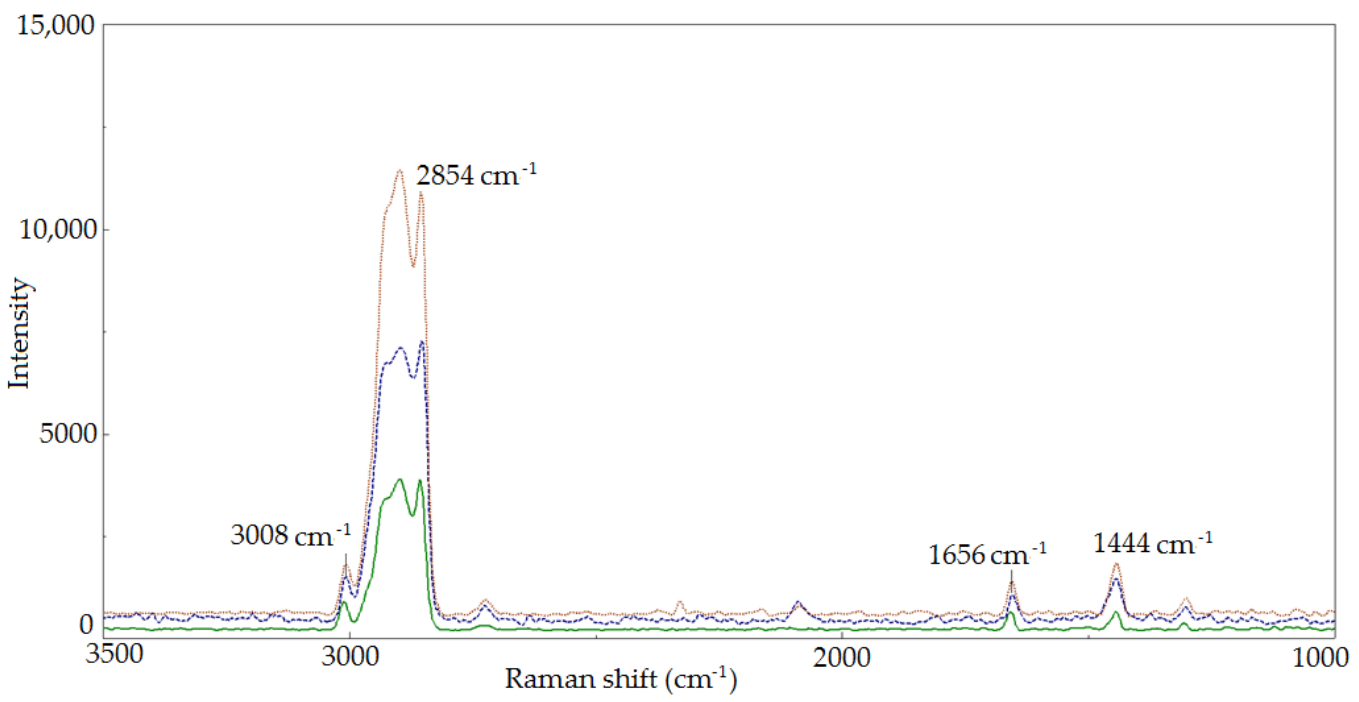

Figure 1. Raman spectra of A oil (green line) and A_CO $\mathrm{CO}_{2}$ (blue line) as well as A_O $\mathrm{O}_{2}$ (red line) modified oils, in the $3500 \mathrm{~cm}^{-1}-1000 \mathrm{~cm}^{-1}$ range.

Table 3. Chemical shifts and vibrational modes present in the Raman spectra of oils.

\begin{tabular}{cccc}
\hline Raman Shift, $\mathbf{c m}^{-\mathbf{1}}$ & Bond & Group & Vibrational Mode \\
\hline $3100-2800$ & $=\mathrm{C}-\mathrm{H}, \mathrm{C}-\mathrm{H}$ & $-\mathrm{CH}_{3},-\mathrm{CH}_{2}$ & stretching \\
1656 & $\mathrm{C}=\mathrm{C}$ & $c i s \mathrm{RCH}=\mathrm{CHR}$ & stretching \\
1444 & $\mathrm{C}-\mathrm{H}$ & $-\mathrm{CH}_{2}$ & stretching \\
1300 & $-\mathrm{C}-\mathrm{H}$ & $-\mathrm{CH}_{2}$ & scissoring \\
1266 & $=\mathrm{C}-\mathrm{H}$ & $-\mathrm{CH}_{2}$ & twisting \\
1087 & $\mathrm{C}-\mathrm{C}$ & $-\left(\mathrm{CH}_{2}\right)_{\mathrm{n}}$ & stretching \\
\hline
\end{tabular}

Based on the Raman spectra analysis of the studied A, A_CO $\mathrm{O}_{2}$ and A_O $\mathrm{O}_{2}$ oils, the modification influence on the fatty acids unsaturation degree change was evaluated. To do this, the ratio of bands intensity at 1656 and $1444 \mathrm{~cm}^{-1}\left(\mathrm{I}_{1656} / \mathrm{I}_{1444}\right)$ as well as bands at 3008 and $2854 \mathrm{~cm}^{-1}\left(\mathrm{I}_{3008} / \mathrm{I}_{2854}\right)$, resulting from the vibration of characteristic functional groups, was calculated. The ratio of the number of $\mathrm{C}=\mathrm{C}$ double bonds to the number of $\mathrm{C}-\mathrm{C}$ single bonds in the fatty acids of the evaluated oils was determined, and thus the influence of the modification process conditions on unsaturation degree change was estimated (Figure 2).

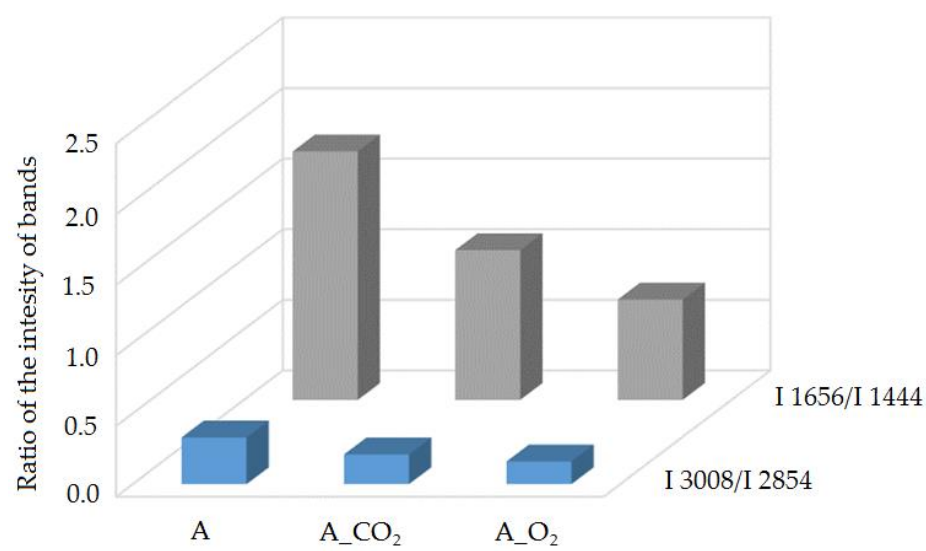

Figure 2. The influence of the modification process on the change in the unsaturation degree of fatty acids in the researched oils: A, A_CO $\mathrm{CO}_{2}$ and $\mathrm{A} \_\mathrm{O}_{2}$, expressed by $\mathrm{I}_{1656} / \mathrm{I}_{1444}$ and $\mathrm{I}_{3008} / \mathrm{I}_{2854}$ bands intensity ratio. 
The modification process of oil A, conducted for the purpose of obtaining base oils with a higher viscosity class, led to changes in the structure. It was found that the oil modification process carried out in the presence of $\mathrm{CO}_{2}$ solvent was more beneficial because the established viscosity of $\mathrm{A}_{-} \mathrm{CO}_{2}$ oil was obtained by smaller structure changes, evaluated on the basis of the $\mathrm{I}_{1656} / \mathrm{I}_{1444}$ and $\mathrm{I}_{3008} / \mathrm{I}_{2854}$ band intensity ratio. The basis for comparison with analytical parameters, especially iodine number LJ, was identified bands from the Raman spectra of the studied $\mathrm{I}_{1656} / \mathrm{I}_{1444}$ oils, which characterized the unsaturation degree of the fatty acids (Figure 3).

It was possible to compare the results of Raman spectroscopy with the iodine number because in both cases the number of double bonds in oil is determined. Raman spectroscopy allowed us to calculate the ratio of the number of $\mathrm{C}=\mathrm{C}$ double bonds to the number of $\mathrm{C}-\mathrm{C}$ single bonds in the oil, where a higher value of the ratio of those bands indicates a higher degree of oil unsaturation. The iodine number determines the number of grams of iodine necessary for the saturation of multiple bonds. The higher the iodine number value the greater the number of double bonds that the fatty acids in the oil contain. It was indicated that the Raman spectra allowed us to estimate the iodine number of oils.

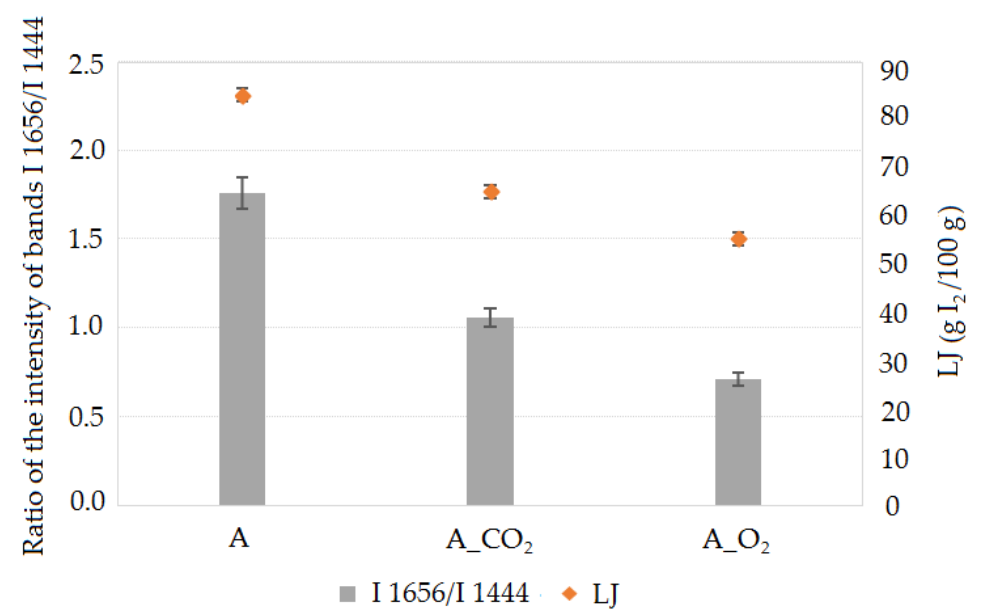

Figure 3. The influence of the A oil modification process on the fatty acids unsaturation change in A_CO $\mathrm{CO}_{2}$ and $\mathrm{A} \_\mathrm{O}_{2}$ oils, expressed by the $\mathrm{I}_{1656} / \mathrm{I}_{1444}$ bands intensity ratio and LJ iodine number.

The use of Raman spectroscopy also allowed the evaluation of the thermal activation's influence on the unsaturation degree change of the researched oils. Samples of A, A_CO $\mathrm{O}_{2}$ and A_O $\mathrm{O}_{2}$ oils were subjects to thermal activation in a laboratory test under the conditions of continuous oxygen activity at $80^{\circ} \mathrm{C}$ and $120^{\circ} \mathrm{C}$. Based on that, the oils' oxidation stability was evaluated as well as the oxidation induction time (Table 1). During the tests the Raman spectra of the oxidized oils were recorded. They were compared with the spectra obtained before the oxidation process. Exemplary spectra are shown below in Figures 4 and 5. 


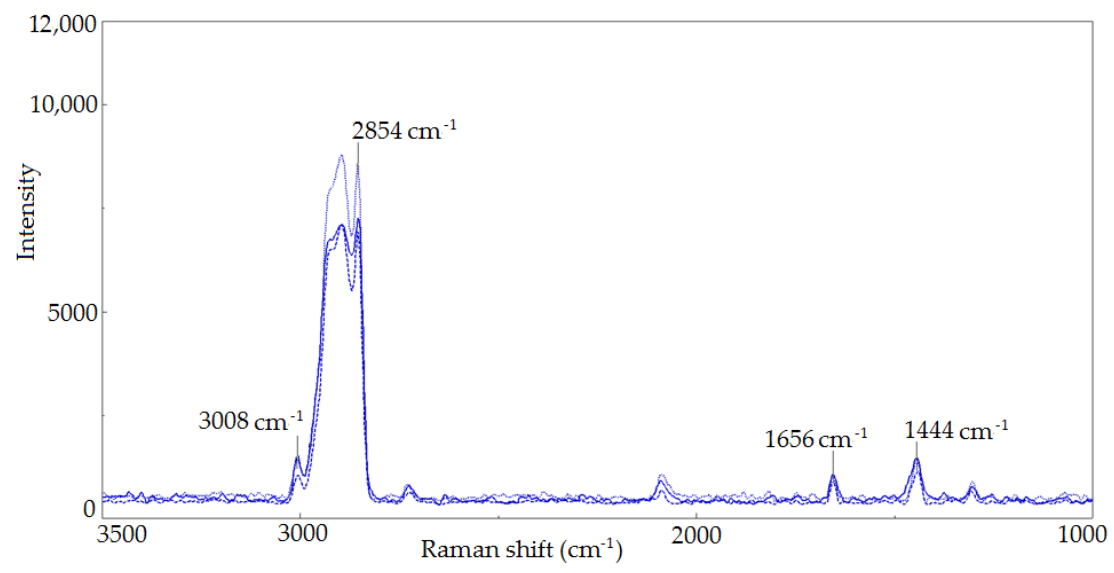

Figure 4. Raman spectra of $\mathrm{A} \_\mathrm{CO}_{2}$ oil (blue line), $\mathrm{A} \_\mathrm{CO}_{2} \_80$ oil, oxidized at $80{ }^{\circ} \mathrm{C}$ (— blue line) and A_CO $2 \_120$ oil, oxidized at $120^{\circ} \mathrm{C}$ (@eceoblue line), in the $3500 \mathrm{~cm}^{-1}-1000 \mathrm{~cm}^{-1}$ range.

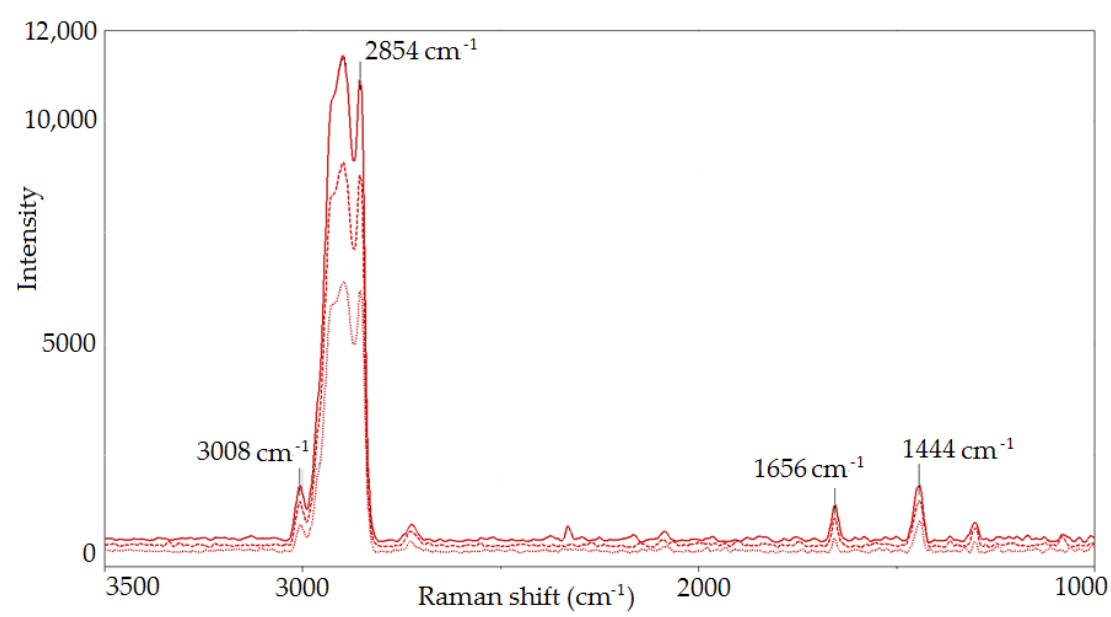

Figure 5. Raman spectra of $\mathrm{A} \_\mathrm{O}_{2}$ oil (red line), $\mathrm{A} \_\mathrm{O}_{2} \_80$ oil, oxidized at $80{ }^{\circ} \mathrm{C}$ (— red line) and

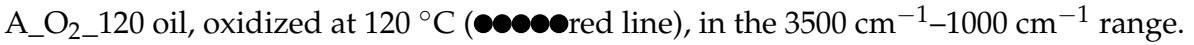

The degree of unsaturation of the oxidized oils and the influence of oxidation on that change were evaluated on the basis of the obtained spectra. The band intensity ratio at 1656 and $1444 \mathrm{~cm}^{-1}$ $\left(\mathrm{I}_{1655} / \mathrm{I}_{1438}\right)$ as well as at 3008 and $2854 \mathrm{~cm}^{-1}\left(\mathrm{I}_{3008} / \mathrm{I}_{2854}\right)$, resulting from the vibration of characteristic functional groups, was determined. Thus, the influence of the modification and oxidation process conditions on the unsaturation degree change was estimated. The band intensity ratio determined for individual oils before and after oxidation was compared-carried out at $80^{\circ} \mathrm{C}$ and $120^{\circ} \mathrm{C}$ for A oil before and A_80, A_120 after oxidation, A_CO $\mathrm{CO}_{2}$ oil before and $\mathrm{A} \_\mathrm{CO}_{2} \_80$ A_CO $\mathrm{CO}_{2} 120$ after oxidation, and for $\mathrm{A} \_\mathrm{O}_{2}$ oil before and $\mathrm{A} \_\mathrm{O}_{2} \_80 \mathrm{~A} \_\mathrm{O}_{2} \_120$ after oxidation (Figure 6).

In the oils' spectra after the oxidation test at $80{ }^{\circ} \mathrm{C}$ and $120{ }^{\circ} \mathrm{C}$, bands at $2854 \mathrm{~cm}^{-1}$ and $1656 \mathrm{~cm}^{-1}$ were smaller than those for the initial oils. For all studied oils after the test, the change in structure was the smallest for initial A oil in comparison to modified $\mathrm{A}_{-} \mathrm{CO}_{2}$ and $\mathrm{A} \mathrm{O}_{2}$ oils.

The determined oxidation stability confirmed the higher resistance to oxidation of raw oil in comparison to modified oils, which is connected to the oil's molecular structure. The oil modification process initiated changes in the structure and the thermal activities augmented the changes. Oils in the VG 150 viscosity class result from the modification, but the modification process carried out in the presence of $\mathrm{CO}_{2}$ had a smaller effect on the fatty acid unsaturation degree-diagnostic bands present in the Raman spectrum, which was also confirmed through analytical methods. 


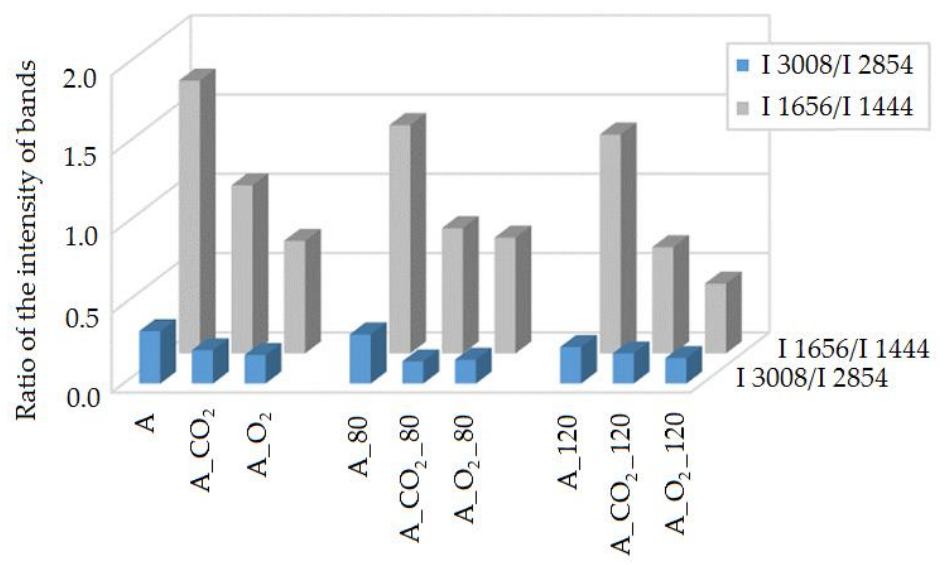

Figure 6. The influence of oxidation on the change in fatty acids unsaturation degree of the researched oils before and after oxidation, at $80{ }^{\circ} \mathrm{C}$ and $120{ }^{\circ} \mathrm{C}$, expressed by $\mathrm{I}_{1656} / \mathrm{I}_{1444}$ and $\mathrm{I}_{3008} / \mathrm{I}_{2854}$ band intensity ratio.

\subsubsection{UV-VIS Spectroscopy}

The raw oil (A) does not exhibit any absorption above $300 \mathrm{~nm}$. In the 200-400 nm region, a weak absorption band is present $\lambda=234 \mathrm{~nm}, \varepsilon=0.046$. In the spectra of both modified oils, two additional absorption maxima are present: $\lambda=218 \mathrm{~nm}, \varepsilon=0.18$ and $\lambda=268 \mathrm{~nm}, \varepsilon=0.032$ for A_O ${ }_{2}$ and $\lambda=218 \mathrm{~nm}$, $\varepsilon=0.168$ and $\lambda=268 \mathrm{~nm}, \varepsilon=0.036$ for $\mathrm{A}_{-} \mathrm{CO}_{2}$ (Figure 7).

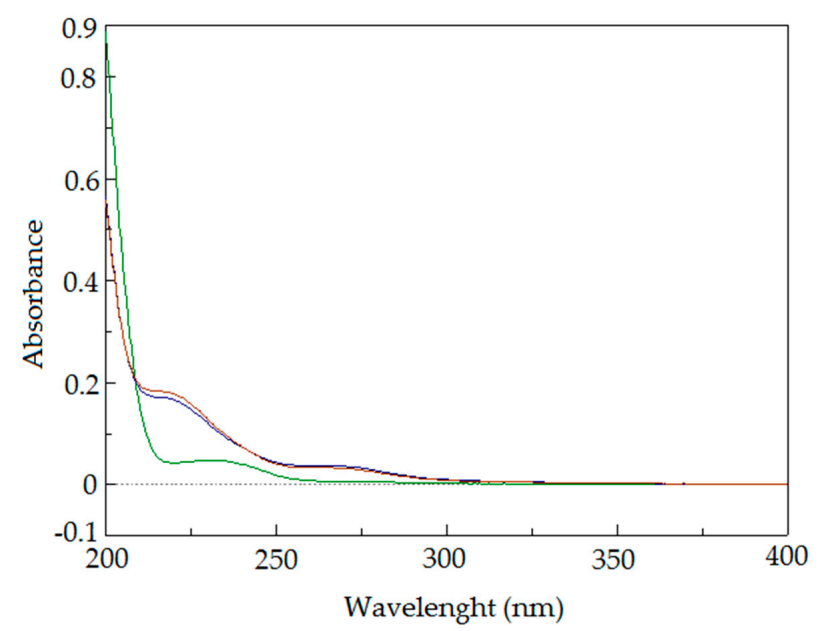

Figure 7. UV-VIS spectra of modified oils $\mathrm{A}_{-} \mathrm{CO}_{2}$ (blue line) and $\mathrm{A}_{-} \mathrm{O}_{2}$ (red line) superimposed on the spectrum of raw Crambe abyssinica oil A (green line).

\subsubsection{FT-IR Spectroscopy}

Figure 8 shows the ATR-FTIR spectra of raw oil A and modified oils A_ $\mathrm{O}_{2}$ and A_CO $\mathrm{CO}_{2}$. The major bands are associated with trifatty acid esters of glycerol which are main components of the oils. 


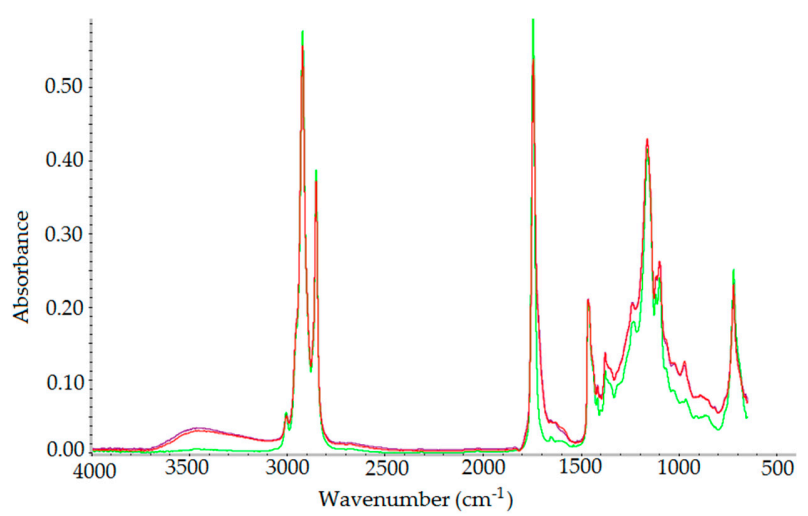

(a)
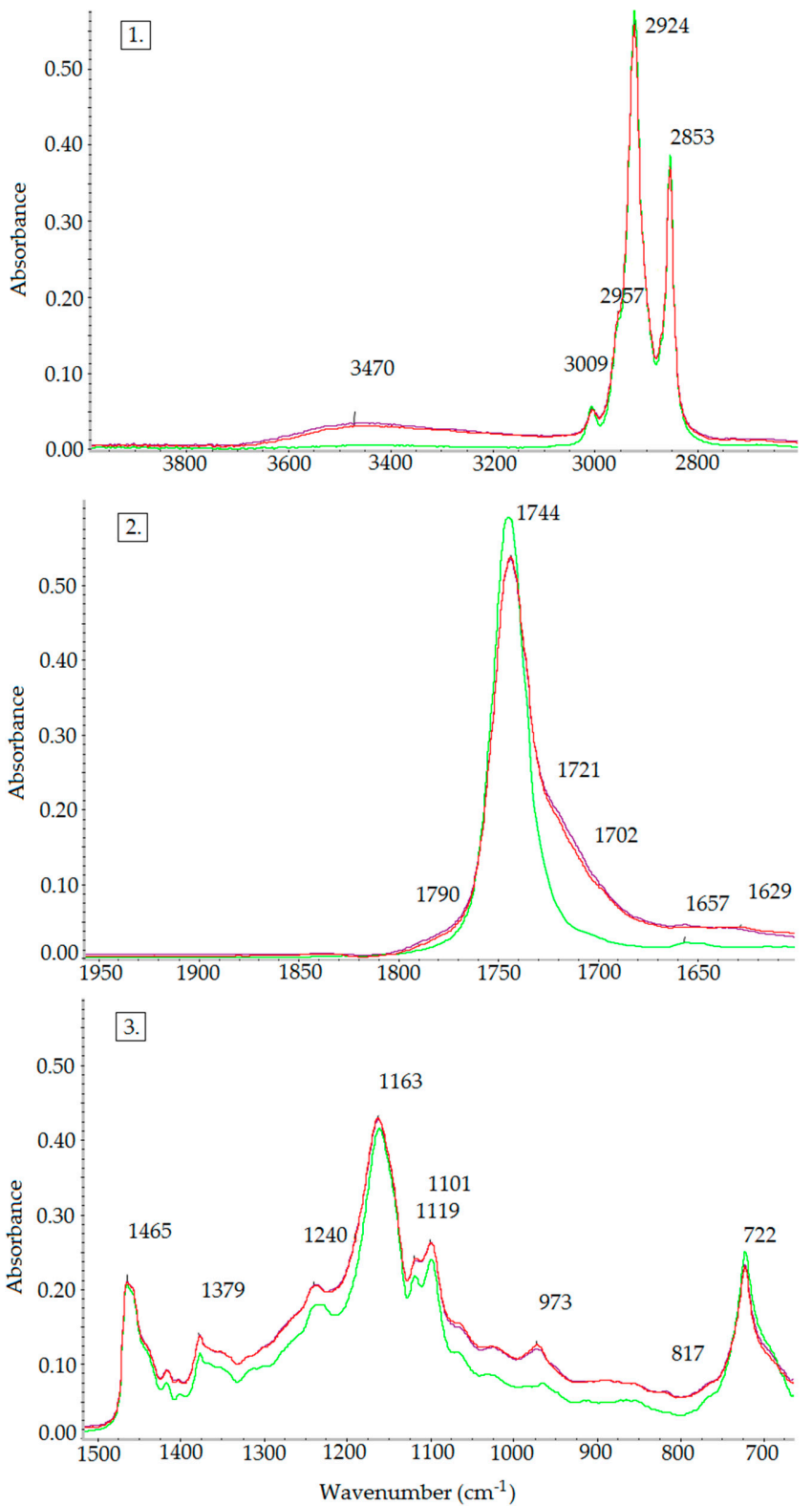

(b)

Figure 8. (a) ATR-FTIR spectra of oils: raw Crambe abyssinica oil A (green line), A_O 2 (red line), A_ $\mathrm{CO}_{2}$ (blue line). (b) ATR-FTIR spectra of oils: raw Crambe abyssinica oil A (green line), A_O 2 (red line), $\mathrm{A}_{-} \mathrm{CO}_{2}$ (blue line): b1. In the region of $3800-2400 \mathrm{~cm}^{-1} \mathbf{b 2}$. In the region of $1950-1600 \mathrm{~cm}^{-1}$ b3. In the region of $1500-650 \mathrm{~cm}^{-1}$. 
All recorded spectra showed absorption bands at different wavenumbers, as follows: $3005 \mathrm{~cm}^{-1}$ $\left(\gamma_{\mathrm{C}-\mathrm{H}}\right.$ of cis double bonds $\left.=\mathrm{CH}\right)$, shoulder at $2955 \mathrm{~cm}^{-1}\left(\gamma_{\mathrm{C}-\mathrm{H}}\right.$ of aliphatic $\left.\mathrm{CH}_{3}\right), 2922$ and $2853 \mathrm{~cm}^{-1}$ $\left(\gamma_{\mathrm{C}-\mathrm{H}}\right.$ of $\left.\mathrm{CH}_{2}\right), 1744 \mathrm{~cm}^{-1}\left(\gamma_{\mathrm{C}=\mathrm{O}}\right.$ of ester carbonyl functional groups of triglycerides $(\mathrm{O}-\mathrm{C}=\mathrm{O})$, weak shoulder at 1719 and $1700 \mathrm{~cm}^{-1}\left(\gamma_{\mathrm{C}=\mathrm{O}}\right.$ of carbonyl functional groups of ketones and free fatty acids, $1655 \mathrm{~cm}^{-1}$ ( $\gamma_{\mathrm{C}=\mathrm{C}}$ of cis-olefins $), 1463,1458 \mathrm{~cm}^{-1}\left(\delta_{\mathrm{C}-\mathrm{H}}\right.$ of $\mathrm{CH}_{2}$ and $\mathrm{CH}_{3}$ aliphatic groups), $1418 \mathrm{~cm}^{-1}$ (rocking vibration of C-H bonds of cis-disubstiuted olefins), $1397 \mathrm{~cm}^{-1}\left(\delta_{\mathrm{C}-\mathrm{H}}\right.$ in plane of C-H of cis-olefinic groups), $1376 \mathrm{~cm}^{-1}$ ( $\delta_{\mathrm{C}-\mathrm{H}}$ of $\mathrm{C}-\mathrm{H}$ of $\mathrm{CH}_{2}$ groups), 1237, 1160, 1118 and $1096 \mathrm{~cm}^{-1}$ ( $\gamma_{\mathrm{C}-\mathrm{O}}$ of ester groups),

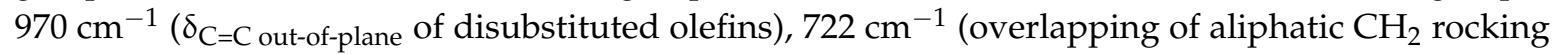
vibration and out of plane vibration of cis-disubstituted olefins) [44].

By comparing the spectra of raw and modified oils in 3800-2400 $\mathrm{cm}^{-1}$ region, the change in the absorbance at $3465 \mathrm{~cm}^{-1}$ ( $\gamma_{\mathrm{O}-\mathrm{H}}$ in $\mathrm{OH}$ groups) is noticeable, as the height of this band increased after modification. The band at $3005 \mathrm{~cm}^{-1}$ decreased slightly after treatment and the increase in absorbance at $970 \mathrm{~cm}^{-1}$ indicated the formation of trans $\mathrm{C}=\mathrm{C}$ bonds.

The examination of ATR-FTIR spectra of raw and modified oils revealed the changes in the following regions: the $\mathrm{OH}$ stretching region of hydroxyl groups between 3600 and $3100 \mathrm{~cm}^{-1}$, hydrogen stretching vibrations between 3050 and $2800 \mathrm{~cm}^{-1}$ and carbonyl stretching vibrations between 1800 and $1680 \mathrm{~cm}^{-1}$. These changes reflect the modification process leading to the alteration of structure and properties of the raw C. abyssinica oil.

Comparing the spectra of raw and modified oils, absorbance changes at $3465 \mathrm{~cm}^{-1}\left(\gamma_{\mathrm{O}-\mathrm{H}}\right.$ in $\mathrm{OH}$ groups) are observed. The height of this band increased after modification most likely due to the formation of $-\mathrm{COOH}$. Likewise the absorbance between 1800 and $1680 \mathrm{~cm}^{-1}$ after modification decreased and the broadening of the band is observed, which is associated with appearance of new carbonyl groups originated from ketones, aldehydes and free fatty acids. The resulting decrease of band at $1744 \mathrm{~cm}^{-1}$ is caused by the loss of the carbonyl groups of fatty esters. The band at $3005 \mathrm{~cm}^{-1}$ and $1650 \mathrm{~cm}^{-1}$ slightly decreased after treatment, which is associated with the decrease of $\operatorname{cis} \mathrm{C}=\mathrm{C}$ bonds. At the same time absorbance at $970 \mathrm{~cm}^{-1}$ increased indicating the formation of trans $\mathrm{C}=\mathrm{C}$ bonds.

Deconvolution of the spectra of raw oil A in the carbonyl range between 1770 and $1680 \mathrm{~cm}^{-1}$ reveals two carbonyl bands at $1745 \mathrm{~cm}^{-1}$ and at $1733 \mathrm{~cm}^{-1}$ while deconvolution of the modified oils A_O $\mathrm{O}_{2}$ and $\mathrm{A} \_\mathrm{CO}_{2}$ spectra shows additional two carbonyl bands at about $1720 \mathrm{~cm}^{-1}$ and at $1700 \mathrm{~cm}^{-1}$ which in comparison does not show in case of raw oil (A) (Figure 9a-c). The band at $1720 \mathrm{~cm}^{-1}$ results from the creation of aldehydes, ketones, esters and band at $1700 \mathrm{~cm}^{-1}$ represents the appearance of free fatty acids [45]. Gaussian/Lorenzian deconvolution model with middle sensitivity and wave width of $4 \mathrm{~cm}^{-1}$ gave good compatibility of original spectrum and the total of all deconvolution bands.

ATR-FTIR spectroscopy thus seems to be an appropriate and comprehensive tool for monitoring the chemical changes appearing during modifications of the Crambe abissinica oil. 

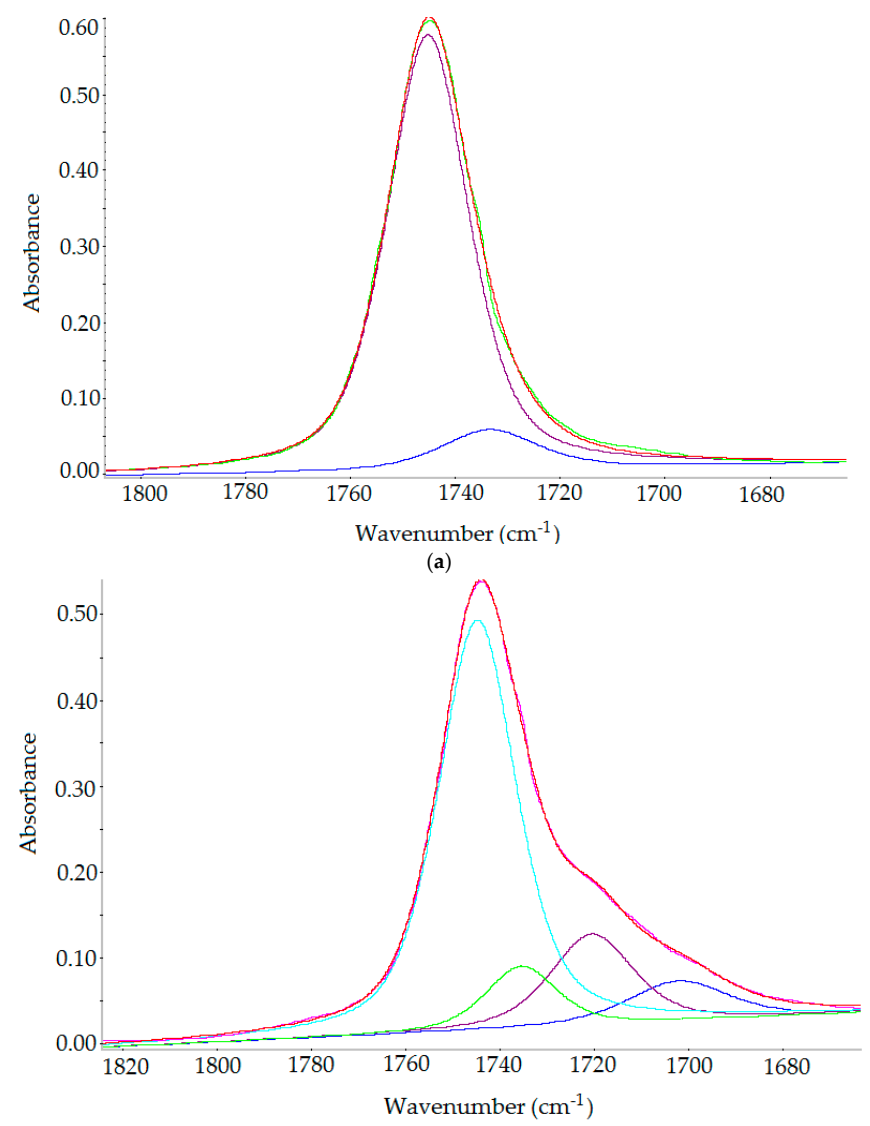

(b)

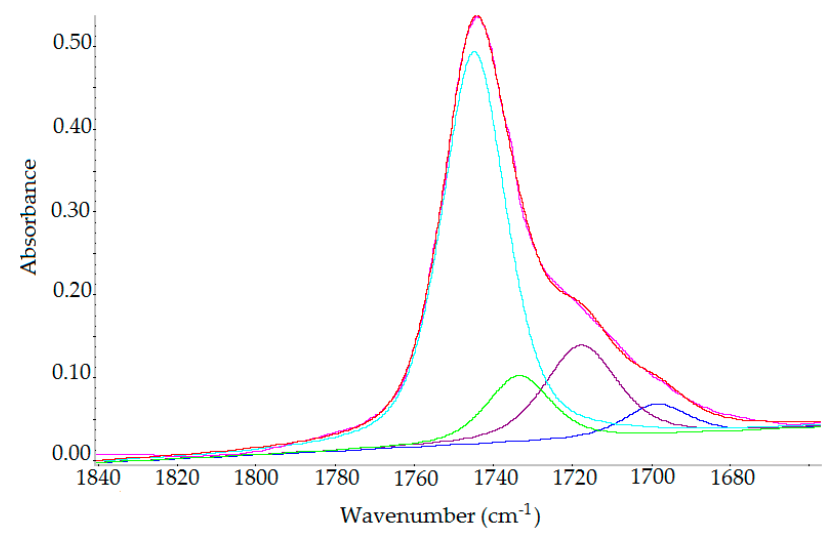

(c)

Figure 9. (a) Deconvolution of carbonyl bands of raw oil A: $1745 \mathrm{~cm}^{-1}$ (violet line), $1734 \mathrm{~cm}^{-1}$ (blue line), original spectrum (green line), total of all deconvolution bands (red line). (b) Deconvolution of carbonyl bands of oil A_O $\mathrm{O}_{2}: 1745 \mathrm{~cm}^{-1}$ (sky-blue line), $1735 \mathrm{~cm}^{-1}$ (green line), $1720 \mathrm{~cm}^{-1}$ (violet line), $1702 \mathrm{~cm}^{-1}$ (blue line), original spectrum (pink line), total of all deconvolution bands (red line). (c) Deconvolution of carbonyl bands of oil A_CO $\mathrm{CO}_{2}: 1745 \mathrm{~cm}^{-1}$ (sky-blue line), $1734 \mathrm{~cm}^{-1}$ (green line), $1718 \mathrm{~cm}^{-1}$ (violet line), $1700 \mathrm{~cm}^{-1}$ (blue line), original spectrum (pink line), total of all deconvolution bands (red line).

\subsubsection{NMR Spectroscopy}

Based on the ${ }^{1} \mathrm{H}-\mathrm{NMR}$ spectra of crude Crambe abyssinica oil (Figure 10), it was determined that signals at a chemical shift of $0.9 \mathrm{ppm}$ originate from the $-\underline{\mathrm{C}}_{3}$ groups. The integral calculations (Table 4) were made by assuming that there are three such groups in the triglyceride molecule, equal to nine protons. On this basis, it was determined that the multiplet at $5.35 \mathrm{ppm}$ corresponds to eight 
hydrogen atoms derived from vinyl groups (- $\underline{\mathrm{H}}=\mathrm{C} \underline{\mathrm{H}}-)$. Therefore, the distribution of double bonds in the molecular chains of triglyceride is possible in two ways: two moieties consisting of two double bonds connected by a methylene group (the so called bis-allylic group $=\mathrm{CH}-\mathrm{CH}_{2}-\mathrm{CH}=$ ) or one such moiety and two isolated double bonds (Figure 11).

Table 4. Chemical shifts and integral values in ${ }^{1} \mathrm{H}-\mathrm{NMR}$ spectra of crude oil A and oils after oxidation (A_CO $\mathrm{CO}_{2}$ in the presence of $\mathrm{CO}_{2}$ and $\mathrm{A} \_\mathrm{O}_{2}$ without $\mathrm{CO}_{2}$ ).

\begin{tabular}{|c|c|c|c|c|}
\hline \multirow{2}{*}{ Proton } & \multirow{2}{*}{$\delta[p p m]$} & \multicolumn{3}{|c|}{ Integral } \\
\hline & & Crambe abyssinica Oil & A_O $\mathrm{O}_{2}$ & $\mathrm{~A}_{-} \mathrm{CO}_{2}$ \\
\hline $\mathrm{CH}_{2} \mathrm{CH}_{3}$ & 0.88 & 7.08 & 7.81 & 7.75 \\
\hline$\left(\mathrm{CH}_{2}\right)_{\mathrm{n}}$ & $1.35-1.20$ & 60.23 & 62.36 & 62.13 \\
\hline $\mathrm{CH}_{2} \mathrm{CH}_{3}$ & $1.65-1.55$ & 5.96 & 7.38 & 7.09 \\
\hline $\mathrm{CH}_{2}-\mathrm{CH}=\mathrm{CH}-\mathrm{CH}_{2}-$ & $2.10-1.97$ & 9.37 & 6.94 & 7.21 \\
\hline $\mathrm{CH}_{2} \mathrm{COO}$ & $2.34-2.28$ & 5.34 & 6.12 & 6.08 \\
\hline $\mathrm{CH}=\mathrm{CH}-\mathrm{CH}_{2}-\mathrm{CH}=\mathrm{CH}$ & $2.83-2.75$ & 1.34 & 0.35 & 0.38 \\
\hline $\mathrm{OCH}_{2} \mathrm{CH}(\overrightarrow{\mathrm{O}}) \mathrm{CH}_{2} \mathrm{O}$ & $4.32-4.12$ & 3.65 & 3.83 & 3.74 \\
\hline $\mathrm{OCH}_{2} \mathrm{CH}(\mathrm{O}) \overline{\mathrm{CH}} \overline{\mathrm{O}}_{2} \mathrm{O}$ & $5.28-5.20$ & 0.94 & 0.93 & 0.88 \\
\hline $\mathrm{C} \underline{\mathrm{H}}=\mathrm{C} \underline{\mathrm{H}}$ & $5.43-5.28$ & 5.54 & 3.42 & 3.58 \\
\hline
\end{tabular}
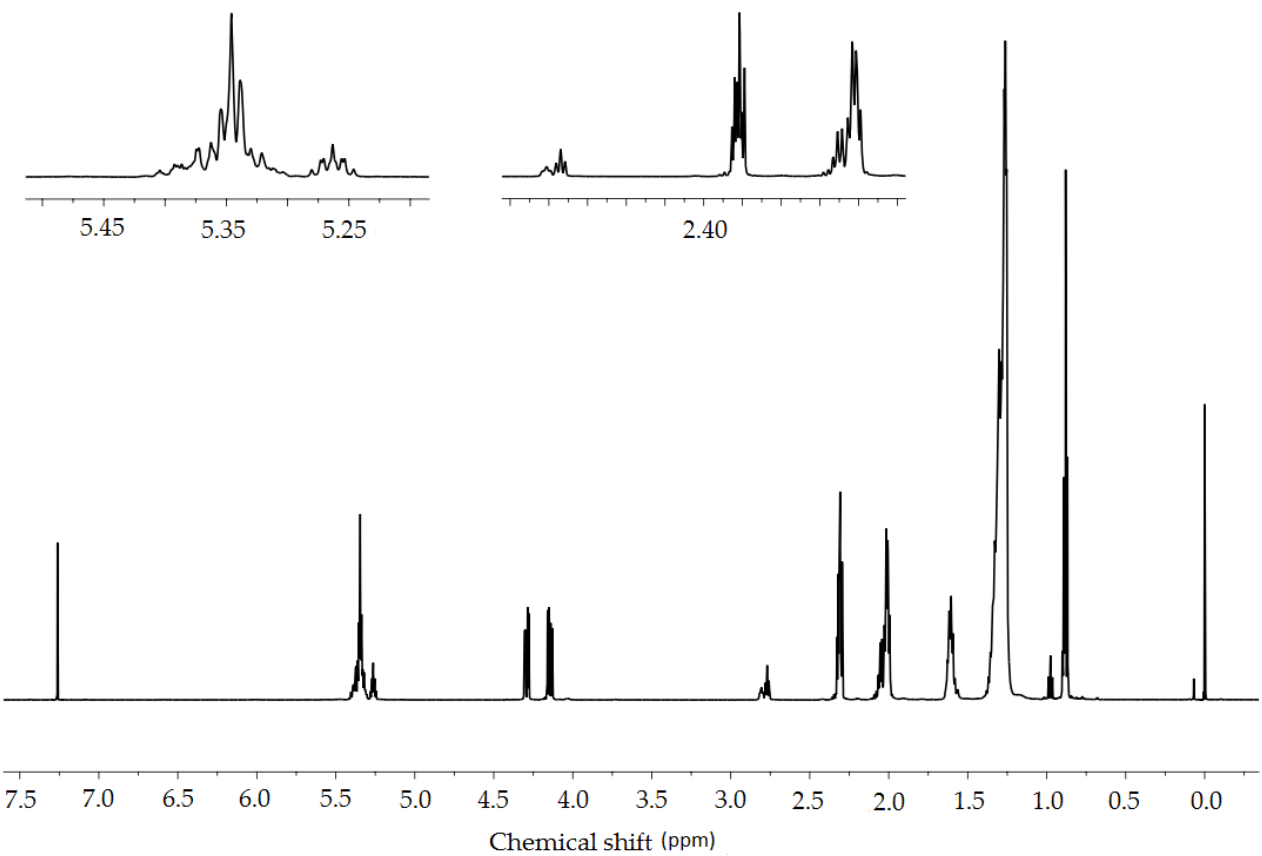

Figure 10. ${ }^{1} \mathrm{H}-\mathrm{NMR}$ spectrum $\left(600 \mathrm{MHz}, \mathrm{CDCl}_{3}\right)$ of crude Crambe abyssinica oil: $\delta 0.88(\mathrm{t}, 9 \mathrm{H}$, $\left.J=0.88 \mathrm{~Hz}, \mathrm{CH}_{2} \mathrm{CH}_{3}\right), 1.35-1.20\left(\mathrm{~m}, 70 \mathrm{H},\left(\mathrm{CH}_{2}\right)_{\mathrm{n}}\right), 1.65-1.55\left(\mathrm{~m}, 6 \mathrm{H}, \mathrm{CH}_{2} \mathrm{CH}_{3}\right), 2.10-1.97(\mathrm{~m}, 12 \mathrm{H}$, $\left.\mathrm{CH}_{2}-\mathrm{CH}=\mathrm{CH}-\mathrm{CH}_{2}-\right), 2.34-2.28\left(\mathrm{~m}, 6 \mathrm{H}, \mathrm{CH}_{2} \mathrm{COO}\right), 2.83-2.75\left(\mathrm{~m}, 2 \mathrm{H}, \mathrm{CH}=\overline{\mathrm{CH}}-\mathrm{CH}_{2}-\mathrm{CH}=\mathrm{CH}\right), 4.32-4.12$ $\left(\overline{\mathrm{m}}, 4 \mathrm{H}, \mathrm{OCH}_{2} \mathrm{C} \overline{\mathrm{H}}(\mathrm{O}) \mathrm{CH}_{2} \mathrm{O}\right), 5.28-5.20\left(\overline{\mathrm{m}}, 1 \mathrm{H}, \mathrm{OCH}_{2} \mathrm{C} \underline{\mathrm{H}}(\mathrm{O}) \mathrm{CH}_{2} \mathrm{O}\right), 5.43-5.28(\overline{\mathrm{m}}, 8 \mathrm{H}, \underline{\mathrm{CH}}=\mathrm{CH})$.
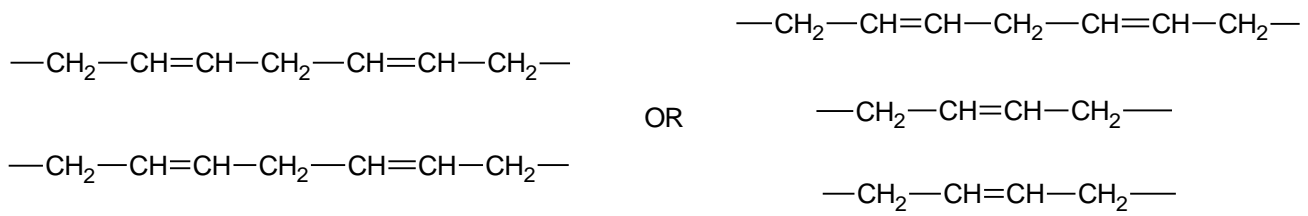

Figure 11. The double bond distribution possibilities.

Based on the integrals of peaks originating from the allylic methylene groups (2.0 and $2.8 \mathrm{ppm}$ ), it was determined that there are two hydrogen atoms originating from the bis-allylic methylene group according to the structure $=\mathrm{CH}-\mathrm{CH}_{2}-\mathrm{CH}=$ and 12 hydrogen atoms that are derived from the allylic 
protons $-\mathrm{CH}_{2}-\mathrm{CH}=\mathrm{CH}-\mathrm{CH}_{2}-$. This information allowed us to figure out the general triglyceride structure eliminating one of the above possibilities. In only one chain are there two double bonds (Figure 12).

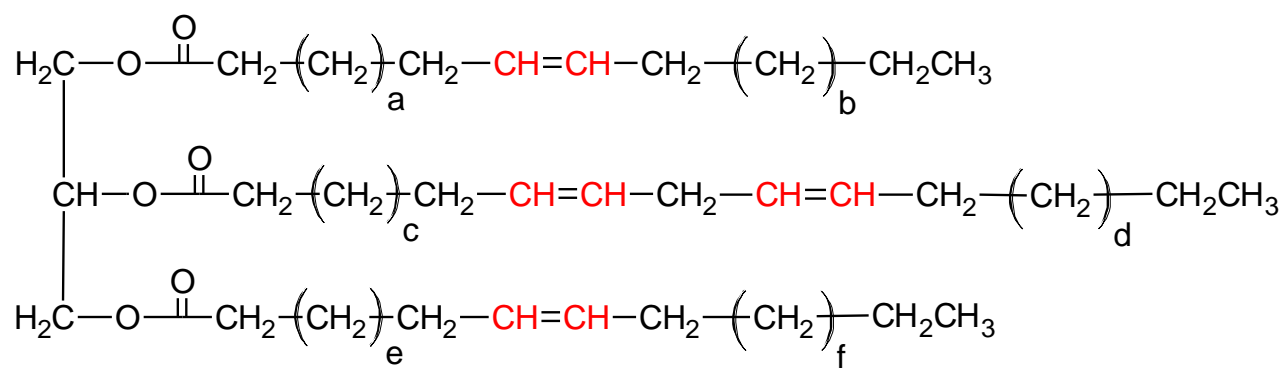

Figure 12. The general structure of the triglyceride.

In addition, the number of hydrogen atoms forming the $-\mathrm{C}_{2}$ - chains was calculated $(70 \mathrm{H})$ and this allowed us to estimate the triglyceride structure. The fatty acid chains that create the molecule probably originate from erucic acid 22:1 and linoleic acid 18:2. Therefore:

$$
\begin{aligned}
& a=7 \\
& b=7 \\
& c=5 \\
& d=2 \\
& e=7 \\
& f=7
\end{aligned}
$$

The structural changes that occurred as a result of the oxidation of Crambe abyssinica oil were determined with the use of ${ }^{1} \mathrm{H}-\mathrm{NMR}$ spectra (Figures 13 and 14). These changes are mainly demonstrated by the decreased intensity of three signals (2.0, 2.8 and $5.35 \mathrm{ppm})$. Comparing the spectrum of the modified oil with the crude oil, a decrease in the value of the integral of the signal deriving from the vinylic protons $-\underline{\mathrm{CH}}=\mathrm{C} \underline{\mathrm{H}}$ - is noticeable (5.35 ppm). Using these values (Table 4), it is possible to calculate the degree of conversion of double bonds:

$$
\alpha_{\mathrm{CH}=\mathrm{CH}}=\frac{5.54-3.42}{5.54} \times 100 \%=38 \%
$$

Another issue worth considering is the signal with $2.8 \mathrm{ppm}$ chemical shift coming from the hydrogen atoms between the two double bonds $=\mathrm{CH}-\mathrm{CH}_{2}-\mathrm{CH}=$. This signal also decreases considerably which indicates the disappearance of double bonds.

In addition, the signal with $2.0 \mathrm{ppm}$ chemical shift derived from the hydrogen atoms in the $\mathrm{CH}_{2}-\mathrm{CH}=\mathrm{CH}-\mathrm{CH}_{2}$ structure is reduced which is another proof of a change in the structure confirming the efficiency of the oxidation of double bonds. 

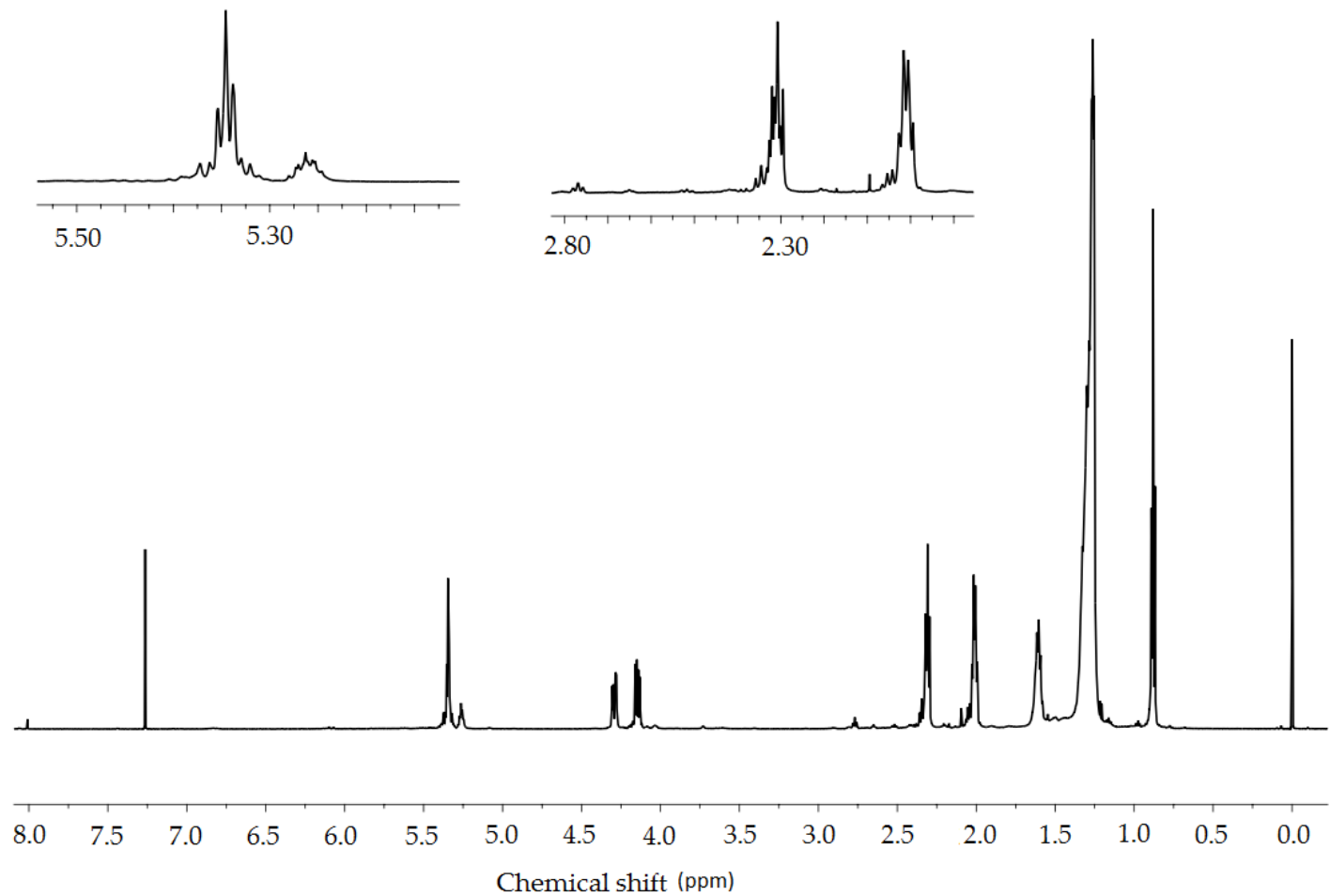

Figure 13. ${ }^{1} \mathrm{H}-\mathrm{NMR}$ spectrum of modified Crambe abyssinica oil in the presence of oxygen.
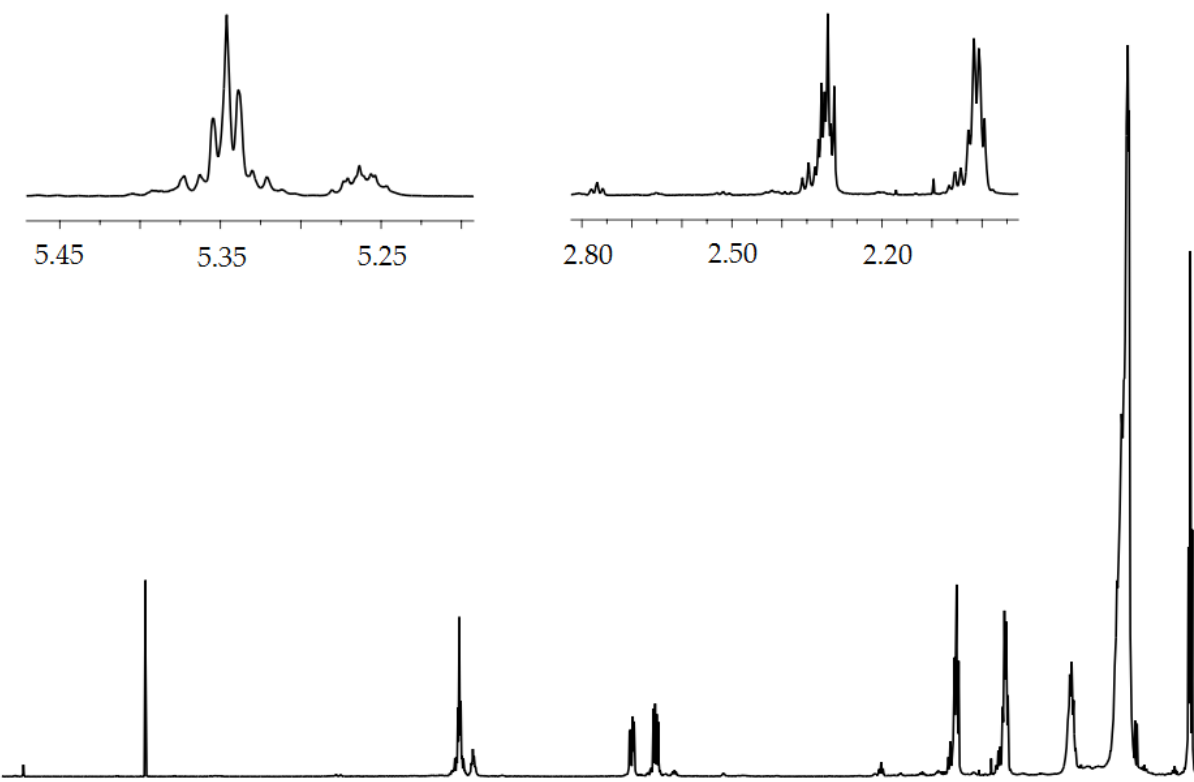

8.0

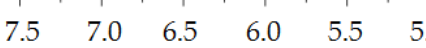

Chemical shift (ppm)

Figure 14. ${ }^{1} \mathrm{H}-\mathrm{NMR}$ spectrum of modified Crambe abyssinica oil in the presence of oxygen and $\mathrm{CO}_{2}$.

The analysis described above also applies to Crambe abyssinica oil oxidized in the presence of carbon dioxide. The differences between the spectra of modified oils are slight. Decreased intensity of signals from vinylic protons (5.35 ppm chemical shift) allowed us to calculate the degree of conversion of double bonds:

$$
\alpha_{\mathrm{CH}=\mathrm{CH}}=\frac{5.54-3.58}{5.54} \times 100 \%=35 \%
$$


In the presence of AIBN (a radical initiator), the oxygen reacts initially with the alkyl radicals of fatty acid chains in the triglyceride to form primary oxidation products-the hydroperoxides.

Those highly reactive hydroperoxides follow several pathways, leading to oxygenated and cross-linked products. For example, they react preferably with the allylic hydrogens to form relatively stable allyl radicals. Those radicals in turn, can react with oxygen finally yielding some oxygenated products (e.g., epoxides, cyclic peroxides, aldehydes, alcohols) or they can recombine with other alkyl radicals yielding cross-linked glycerides. The ratio of the products attributable to propagation and termination steps is mostly influenced by the relative rates of branching and termination pathways [46].

In the IR and Raman spectra of the oxidized oil bands due to hydroxy group are absent. This supports the assumption that the reaction, does not stop at the hydroperoxide or epoxide stage.

On the other hand, during such oxidative treatment radical polymerization of the vegetable oil occurs, resulting in the increase of viscosity. Examination of the ${ }^{1} \mathrm{H}-\mathrm{NMR}$ spectra reveals lack of peaks that can be attributed to epoxides [47]: $3.00 \mathrm{ppm}$ for protons on the epoxy ring is missing and the peak at $1.50 \mathrm{ppm}$ for the methylene protons adjacent to these epoxy groups shows only a negligible intensity. Signals that can be attributed to aldehydes and free acids are barely above the noise level.

Combined evaluation of IR, Raman and NMR data supports the assumption that the double bonds were mainly converted to $\mathrm{C}-\mathrm{C}$ bonds and ether (C-O-C) and / or peroxy (C-O-O-C) bridges.

\section{Materials and Methods}

\subsection{Abyssinian Oil Modification}

The oxidation processes of Abyssinian oil were conducted using equipment composed of three devices: a "limbo" pressure reactor (Büchi, Uster, Switzerland), a metering pump (Blue Shadow, Berlin, Germany) and a thermostat (Julabo, Seelbach, Germany). Starting materials crambe oil, $0.05 \%(w / w)$ NHPI and $0.05 \%(w / w)$ AIBN were fed to the pressure reactor. Then, the reactor was pressurized with $0.25 \mathrm{MPa}$ with oxygen, the temperature was raised to $100{ }^{\circ} \mathrm{C}$ and the pressure was increased to $10 \mathrm{MPa}$ with carbon dioxide. For reactions in pure oxygen, the reactor was pressurized with $0.4 \mathrm{MPa}$. During the process, the temperature and pressure were controlled. If necessary, pressure in the reactor was corrected by the addition of oxygen (for the process without solvent) or $\mathrm{CO}_{2}$ (for the process with solvent).

\subsection{Raman Spectroscopy}

Raman spectra were obtained using an NRS 5100 confocal grating Raman microspectrometer (Jasco Corporation, Tokyo, Japan) which was equipped with a pumped laser with wave length of $532 \mathrm{~nm}$ and a Charged Coupled Device (CCD) detector. The operating conditions of the spectrometer were as follows: diffraction grating 1800 lines $/ \mathrm{mm}$, laser power $5.1 \mathrm{~mW}$, numerical aperture $4000 \mu \mathrm{m}$, resolution $8.4 \mathrm{~cm}^{-1}$, lens magnification $20 \times$, exposure time $15 \mathrm{~s}$.

The method of research was developed. The procedure was the same for each sample. Samples were applied to glass slides having a recess in order to maintain the same thickness of the sample layer. The measurement conditions were established (focusing on the sample, selection of integration time, number of scans, laser power). The Raman spectra of the oils were measured under selected conditions in a way to obtain the appropriate signal-to-noise ratio in the shortest possible time in the entire spectral range. The number of scans of the sample was 5 , the exposure time was $15 \mathrm{~s}$ for a single accumulation, a laser with an excitation line of $532 \mathrm{~nm}$ was used and the measurements were taken at room temperature.

Obtained spectra were the basis for assessing the degree of unsaturation of the tested oils. An intensity ratio of bands at 1656 and $1444 \mathrm{~cm}^{-1}$ was taken into consideration for the analysis. The bands at 1266 and $1300 \mathrm{~cm}^{-1}$ in the analyzed oils were not very characteristic and they were not analyzed. 


\subsection{UV-VIS Spectroscopy}

Spectra were recorded on a JASCO V-650 spectrometer (Jasco Corporation, Tokyo, Japan) using a $1 \mathrm{~cm}$ cuvette. The absorption spectra of the oils diluted with $n$-hexane $\left(C=5 \times 10^{-5} \mathrm{~g} / \mathrm{mL}\right)$ were measured in the region $200-400 \mathrm{~nm}$.

\subsection{FT-IR Specrocsopy}

FTIR-ATR spectra were recorded on Nicolet 6700 FT-IR spectrometer (Thermo Scientific, Waltham, MA, USA) equipped with a $60^{\circ} \mathrm{ZnSe}$ Attenuated Total Reflectance (ATR) accessory. The operating conditions of the spectrometer were as follows: wavelength range of $4000-650 \mathrm{~cm}^{-1}$, 32 scans, resolution of $4 \mathrm{~cm}^{-1}$.

\subsection{NMR Spectroscopy}

${ }^{1} \mathrm{H}-\mathrm{NMR}$ spectra were recorded on Varian spectrometer (Palo Alto, CA, USA) at a frequency of $600 \mathrm{MHz}$ using NMR solvent $\left(\mathrm{CDCl}_{3}\right)$ which was purchased from ACROS Organics (Geel, Belgium). Coupling constants $(J)$ are in Hertz $(\mathrm{Hz})$. All chemical shifts $(\delta)$ are expressed in ppm downfield from TMS as an internal standard.

\subsection{Determination of Modified Oils Properties}

The viscosity-temperature oil properties were evaluated based on the kinematic viscosity determined at $40{ }^{\circ} \mathrm{C}$ and $100{ }^{\circ} \mathrm{C}$ in accordance with the PN EN ISO 3104:2004 norm and viscosity index in accordance with the PN-ISO 2909:2009 norm. The obtained modified oils were tested through the determination of kinematic viscosity and peroxide number in accordance with the PN-EN ISO 3960:2017-03 norm and iodine number in accordance with the PN-EN ISO 3961:2013-10 norm and saponification number in accordance with the PN-EN ISO 3657:2013-10 norm and acid number in accordance with the PN-EN ISO 660:2010 norm.

\section{Conclusions}

The aim of the research was to determine the changes in the chemical structure of oil components caused by its oxidation. For this purpose Raman, UV-Vis, IR and NMR spectroscopy were used for the sample analysis. In a way, all methods confirmed the structure changes occurring during the oxidative modification process. The analysis of the obtained Raman and NMR spectra led to the determination of the degree of fatty acids' unsaturation. Furthermore, the change in the absorption bands and hence structural changes can be confirmed with the use of the IR and UV-Vis spectra. Spectroscopic methods are effective in observing the changes caused by the oxidation of Crambe abyssinica oil and determining the degree of unsaturation of fatty acids.

\section{Patents}

The research described above is the subject of two patent applications concerning vegetable oils' modification entitled "Sposób Modyfikacji Olejów Roślinnych" by Iłowska, J.; Grabowski, R.; Szmatoła, M.; Gniady, J.; Woch, J.; Chrobak, J.; Korasiak, K.; Dejnega, B.; Szwach, I.; Fiszer, R. Patent Applications No. P.425863 and P.425863, which were submitted on 11 June 2018.

Author Contributions: Conceptualization, J.I., J.D.; Methodology, B.O.; Validation, R.G., B.O.; Investigation, J.C., R.G., J.W., I.S. (Izabela Semeniuk), M.W., R.K., M.G.; Writing-Original Draft, M.S., J.C., J.D.; Writing-Review \& Editing, J.C.; Project Administration, J.I., M.S., J.D.; Funding Acquisition, J.I., I.S. (Iwona Szwach), J.D. All authors have read and approved the final version of the manuscript.

Funding: Research realized within the National Centre for Research and Development (Poland) project, within the Smart Growth Operational Programme 2014-2020, Subaction 4.1.2 "Regional scientific-research agendas", "Technology development of new generation of high quality lubricants, for food industry, that guarantee the food safety", years 2017-2019, No. 04.01.02-00-0004/16. 
Conflicts of Interest: The authors declare no conflict of interest.

\section{References}

1. Lankmayr, E.; Mocak, J.; Serdt, K.; Balla, B.; Wenzl, T.; Bandoniene, D.; Gfrerer, M.; Wagner, S. Chemometrical classification of pumpkin seed oils using UV-Vis, NIR and FTIR spectra. J. Biochem. Biophys. Methods 2004, 61, 95-106. [CrossRef]

2. Gromadzka, J.; Wardencki, W. Trends in edible vegetable oils analysis. part b. application of different analytical techniques. Pol. J. Food Nutr. Sci. 2011, 61, 89-99. [CrossRef]

3. Aluyor, E.O.; Ozigagu, C.E.; Oboh, O.I.; Aluyor, P. Chromatographic analysis of vegetable oils: A review. Sci. Res. Essays 2009, 4, 191-197.

4. Nawrocka, A.; Lamorska, J. Determination of food quality by using spectroscopic methods. Adv. Agrophys. Res. 2013, 14. [CrossRef]

5. Yasushi, E. Analytical methods to evaluate the quality of edible fats and oils: The JOCS standard methods for analysis of fats, oils and related materials (2013) and advanced methods. J. Oleo Sci. 2018, 67, 1-10. [CrossRef]

6. Kruzlcova, D.; Mocak, J.; Katsoyannos, E.; Lankmayr, E. Classification and characterization of olive oils by UV-Vis absorption spectrometry and sensorial analysis. J. Food Nutr. Res. 2008, 47, 181-188.

7. Gonçalves, R.P.; Março, P.H.; Valderrama, P. Thermal edible oil evaluation by UV-Vis spectroscopy and chemometrics. Food Chem. 2014, 163, 83-86. [CrossRef]

8. Leder, P.J.S.; Porcu, O.M. The importance of UV-Vis spectroscopy: Application in food products characterization. Scholar J. Food Nutr. 2018, 1. [CrossRef]

9. Vlachos, N.; Skopelitis, Y.; Psaroudaki, M.; Konstantinidou, V.; Chatzilazarou, A.; Tegou, E. Applications of fourier transform-infrared spectroscopy to edible oils. Anal. Chim. Acta 2006, 573-574, 459-465. [CrossRef]

10. Alexa, E.; Dragomirescu, A.; Pop, G.; Jianu, C.; Drago, D. The use of FT-IR spectroscopy in the identification of vegetable oils adulteration. J. Food Agric. Environ. 2009, 7, 20-24.

11. Nigri, S.; Oumeddour, R. Fourier transform infrared and fluorescence spectroscopy for analysis of vegetable oils. MATEC Web Conf. 2013, 5, 04028. [CrossRef]

12. Rohman, A. Infrared spectroscopy for quantitative analysis and oil parameters of olive oil and virgin coconut oil: A review. Int. J. Food Prop. 2017, 20, 1447-1456. [CrossRef]

13. Karim, M.M.; Karim, S.F.E.; Rana, A.A.; Masum, S.M.; Mondol, A.; Israt, S.S. ATR-FTIR spectroscopy and chemometric techniques for the identification of edible vegetable oils. Bangladesh J. Sci. Ind. Res. 2015, 50, 233-240. [CrossRef]

14. Siddiqui, N.; Ahmad, A. Infrared spectroscopic studies on edible and medicinal oils. Int. J. Sci. Environ. Tech. 2013, 2, 1297-1306.

15. Jafari, M.; Kadivar, M.; Keramat, J. Detection of adulteration in iranian olive oils using instrumental (GC, NMR, DSC) methods. J. Am. Oil Chem. Soc. 2009, 86, 103-110. [CrossRef]

16. Popescu, R.; Costinel, D.; Dinca, O.R.; Marinescu, A.; Stefanescu, I.; Ionete, R.E. Discrimination of vegetable oils using NMR spectroscopy and chemometrics. Food Control. 2015, 48, 84-90. [CrossRef]

17. Almoselhy, R.I.M.; Allam, M.H.; Kalyoubi, M.H.E.; Sharkawya, A.A.E. ${ }^{1}$ H-NMR spectral analysis as a new aspect to evaluate the stability of some edible oils. Ann. Agric. Sci. 2014, 59, 201-206. [CrossRef]

18. Vaskova, H.; Buckova, M. Thermal degradation of vegetable oils: Spectroscopic measurement and analysis. Procedia Eng. 2015, 100, 630-635. [CrossRef]

19. Jentzsch, P.V.; Ciobotă, V. Raman spectroscopy as an analytical tool for analysis of vegetable and essential oils. Flavour Fragr. J. 2014, 29, 287-295. [CrossRef]

20. Alvarenga, B.R., Jr.; Xavier, F.A.N.; Soares, F.L.F.; Carneiro, R.L. Thermal stability assessment of vegetable oils by Raman spectroscopy and chemometrics. Food Anal. Methods 2018, 11, 1969-1976. [CrossRef]

21. Jiménez-Sanchidrián, C.; Ruiz, J.R. Use of Raman spectroscopy for analyzing edible vegetable oils. Appl. Spectrosc. Rev. 2016, 51, 417-430. [CrossRef]

22. Adhvaryu, A.; Perez, J.M.; Duda, L.J. Quantitative NMR spectroscopy for the prediction of base oil properties. J. Tribol. Trans. 2008, 43. [CrossRef]

23. Adhvaryu, A.; Perez, J.M.; Singh, I.D.; Tyagi, O.S. Spectroscopic studies of oxidative degradation of base oils. Energy Fuels 1998, 12, 1369-1374. [CrossRef] 
24. Sarpal, A.S.; Kapur, G.S.; Mukherjee, S.; Jain, S.K. Characterization by 13C n.m.r. spectroscopy of base oils produced by different processes. Fuel 1997, 76, 931-937. [CrossRef]

25. Papke, B.L.; Tutunjian, P.N. Applications of ${ }^{13} \mathrm{C}-\mathrm{NMR}$ to predict low temperature viscosity performance of base oils. Tribotest 2006, 12, 211-222. [CrossRef]

26. Krasodomski, W.; Krasodomski, M. GC/MS application in the structural group analysis of basic lubricant oils. Part I-State of knowledge. NAFTA-GAZ 2010, 8, 711-718.

27. Wooton, D.L. Applications of spectroscopy in the fuels and lubrication industry. Appl. Spectrosc. Rev. 2001, 36, 315-332. [CrossRef]

28. Patty, D.J.; Lokollo, R.R. FTIR spectrum interpretation of lubricants with treatment of variation mileage. Adv. Phys. Theor. Appl. 2016, 52, 13-20.

29. Pinchuk, D.; Akochi-Koblé, E.; Cocciardi, R.A.; Pinchuk, J.; van de Voort, F.R.; Sedman, J. Demystifying and Understanding Your Lubricants Using ft-ir Spectroscopic Analysis. Article of Thermal Lube company. Available online: http://thermal-lube.com/wp-content/uploads/2014/02/ DEMYSTIFYING-AND-UNDERSTANDING-YOUR-LUBRICANTS.pdf (accessed on 12 October 2018).

30. Drabik, J.; Iłowska, J.; Gniady, J.; Kozupa, M.; Szmatoła, M.; Semeniuk, I. Wpływ bazy olejowej i składu zagęszczacza na właściwości użytkowe smarów plastycznych. Przem. Chem. 2012, 91, 1922-1926. (In Polish)

31. Drabik, J.; Iłowska, J.; Semeniuk, I.; Bereska, B. Wykorzystanie spektroskopii w podczerwieni do oceny procesu wytwarzania smarów plastycznych. Przem. Chem. 2012, 91, 1957-1962. (In Polish)

32. Drabik, J.; Iłowska, J. Non-toxic lubricant for the food industry. Probl. Eksploat. 2015, 2, 5-13.

33. Iłowska, J.; Chrobak, J.; Grabowski, R.; Szmatoła, M.; Woch, J.; Szwach, I.; Drabik, J.; Trzos, M.; Kozdrach, R.; Wrona, M. Designing lubricating properties of vegetable base oils. Molecules 2018, 23. [CrossRef] [PubMed]

34. Zhu, L. Crambe (Crambe abyssinica). In Industrial Oil Crops; McKeon, T.A., Hayes, D.G., et al., Eds.; Academic Press and AOCS Press: New York, NY, USA, 2016; pp. 195-205.

35. Ferrie, A.M.R.; Caswell, K.L. Applications of doubled haploidy for improving industrial oilseeds. Ind. Oil Crops 2016, 359-378. [CrossRef]

36. Lalas, S.; Gortzi, O.; Athanasiadis, V.; Dourtoglou, E.; Dourtoglou, V. Full characterisation of crambe abyssinica hochst. seed Oil. J. Am. Oil. Chem. Soc. 2012, 89, 2253-2258. [CrossRef]

37. Mattson, F.H.; Volpenhein, R.A. The Specific Distribution of Fatty Acids in the Glycerides of Vegetable Fats. J. Biol. Chem. 1961, 236, 1891-1894. [PubMed]

38. Muik, B.; Lendl, B.; Molina-Diaz, A.; Valcarcel, M.J.; Ayora-Canada, M.J. Two-dimensional correlation spectroscopy and multivariate curve resolution for the study of lipid oxidation in edible oils monitored by FTIR and FT-Raman spectroscopy. Anal. Chim. Acta 2007, 593, 54-67. [CrossRef] [PubMed]

39. Brambilla, L.; Riedo, C.; Baraldi, C.; Nevin, A.; Gamberini, M.C.; D'Andrea, C.; Chiantore, O.; Goidanich, S.; Toniolo, L. Characterization of fresh and aged natural ingredients used in historical ointments by molecular spectroscopic techniques: IR, Raman and fluorescence. Anal. Bioanal. Chem. 2011, 401, 1827-1837. [CrossRef] [PubMed]

40. El-Abassy, R.M.; Donfack, P.; Materny, A. Rapid determination of free fatty acid in extra virgin olive oil by Raman spectroscopy and multivariate analysis. J. Am. Oil Chem. Soc. 2009, 86, 507-511. [CrossRef]

41. El-Abassy, R.M.; Donfack, P.; Materny, A. Assessment of conventional and microwave heating induced degradation of carotenoids in olive oil by VIS Raman spectroscopy and classical methods. Food Res. Int. 2010, 43, 694-700. [CrossRef]

42. Muik, B.; Lendl, B.; Molina-Diaz, A.; Valcarcel, M.J.; Ayora-Canada, M.J. Direct monitoring of lipid oxidation in edible oils by Fourier transform Raman spectroscopy. Chem. Phys. Lipids 2005, 134, 173-182. [CrossRef]

43. Drabik, J.; Kozdrach, R.; Wolszczak, M.; Wrona, M. The proecological base oils of highly specialized lubricants. Przem. Chem. 2018, 97, 538-541. [CrossRef]

44. Raba, D.N.; Poiana, M.-A.; Borozan, A.B.; Stef, M.; Radu, F.; Popa, M.-V. Investigation on crude and high-temperature heated coffee oil by ATR-FTIR spectroscopy along with antioxidant and antimicrobial properties. PLoS ONE 2015, 10, e0138080. [CrossRef] [PubMed]

45. Poiana, M.; Alexa, E.; Munteanu, M. Use of ATR-FTIR spectroscopy to detect the changes in extra virgin olive oil by adulteration with soybean oil and high temperature heat treatment. Open Chem. 2015, 13. [CrossRef] 
46. Dlugogorski, B.Z.; Kennedy, E.M.; Mackie, J.C. Low temperature oxidation of linseed oil: A review. Fire Sci. Rev. 2012, 1, 3. [CrossRef]

47. Xia, W.; Budge, S.M.; Lumsden, M.D. ${ }^{1} \mathrm{H}-\mathrm{NMR}$ Characterization of Epoxides Derived from Polyunsaturated Fatty Acids. J. Am. Oil Chem. Soc. 2016, 93, 467-478. [CrossRef]

Sample Availability: Samples of the compounds are not available from the authors. 